\title{
misonit
}

Revista Educación

ISSN: 0379-7082

ISSN: 2215-2644

revedu@gmail.com

Universidad de Costa Rica

Costa Rica

\section{Factors that Influence Academic Performance: Analyzing Gender Differences in Accounting Students}

Martí-Ballester, Carmen Pilar

Factors that Influence Academic Performance: Analyzing Gender Differences in Accounting Students

Revista Educación, vol. 43, no. 2, 2019

Universidad de Costa Rica, Costa Rica

Available in: http://www.redalyc.org/articulo.oa?id=44058158002

DOI: https://doi.org/10.15517/revedu.v43i2.28916

Esta obra está bajo una Licencia Creative Commons Atribución-NoComercial-SinDerivar 3.0 Internacional. 


\title{
Factors that Influence Academic Performance: Analyzing Gender Differences in Accounting Students
}

\author{
Factores que influyen en el desempeño académico: un análisis de las diferencias de género en estudiante de \\ contabilidad
}

Carmen Pilar Marti-Ballester

Universitat Autónoma de Barcelona, España

carmenpilar.marti@gmail.com

iD http://orcid.org/0000-0003-4085-7677

\author{
DOI: https://doi.org/10.15517/revedu.v43i2.28916 \\ Redalyc: http://www.redalyc.org/articulo.oa?id=44058158002
}

Received: 21 May 2017

Accepted: 23 April 2019

\begin{abstract}
:
The main objective of this article is to analyze gender differences in terms of student academic performance. The study is based on a data sample of 3,219 students attending the Autonomous University of Barcelona. The data was analyzed using the Tobit estimation model and the Tobit-Blinder-Oaxaca Decomposition Method. According to the results obtained, $67.27 \%$ of the differences in male and female academic performance are attributed to observable characteristics. The results obtained also reveal that student intellectual ability, experience with the subject matter, effort made during the course and prior accounting courses taken during high school, all had a significant and positive effect on students of both sexes. On the other hand, scholarships positively influenced the academic performance of only the female students, while the instructor's professional status and the time of the day at which the class was held a negative impact on the academic performance of males. These results have underlying implications for policymakers and instructors. For example, organizations that offer student financial aid, may increase the number of scholarships available for female students, while instructors can better prepare students by having them perform more practical exercises that simulate real-life scenarios they may encounter when entering the job market.
\end{abstract}

KEYWORDS: Academic performance, Gender differences, Undergraduate, Tobit model, Tobit-Blinder-Oaxaca decomposition.

\section{Resumen:}

El principal objetivo del presente trabajo es analizar las diferencias de género en el proceso de aprendizaje del estudiante. Para ello, disponemos de una muestra integrada por datos correspondientes a 3,219 estudiantes adscritos a la Universidad Autónoma de Barcelona. Sobre dichos datos se ha implantado la técnica de estimación Tobit y el método de descomposición Tobit-BlinderOaxaca. Los resultados obtenidos indican que el 67.27 por cien de las diferencias en el rendimiento académico entre hombres y mujeres se explica a través de las características observadas. Los resultados alcanzados también revelan que la capacidad intelectual, la experiencia en la asignatura, el esfuerzo realizado por el estudiante durante el curso y los estudios cursados en materia contable durante su etapa en educación secundaria tienen un efecto positivo y significativo en los estudiantes de ambos sexos. Por el contrario, las becas de estudio sólo influyen positivamente en el rendimiento académico de las mujeres, mientras la categoría profesional del docente y la franja horaria a la que acude el estudiante (varón) influyen negativamente en el rendimiento académico de sus compañeros varones. Estos resultados tienen implicaciones prácticas para los organismos que conceden becas, así como para los profesores. Mientras los organismos que conceden becas deberían mantener o aumentar el número de becas concedidas a las estudiantes (mujeres), los profesores deberían proporcionar material complementario a los estudiantes que simule situaciones reales que puedan encontrarse cuando se incorporen al mercado laboral.

Palabras Clave: Rendimiento académico, Diferencias de género, Estudiantes universitarios, Modelo Tobit, Descomposición Tobit-Blinder-Oaxaca.

\section{INTRODUCTION}

Previous studies have shown that gender plays a decisive role in the academic performance of students enrolled in undergraduate accounting programs (Martí-Ballester, 2012), as well as other factors affect male and female academic performance differently. This article examines factors that influence student academic 
performance based on gender, specifically in the Accounting field, and compares them through a consistent and robust estimator for models with censored data using the Tobit technique and Tobit-Blinder-Oaxaca decomposition on a sample of 3,219 students enrolled at the Autonomous University of Barcelona.

This issue is particularly relevant for (1) the accounting education community, given the high student drop-out and failure rates ${ }^{[1]}$ associated with university financial accounting courses (Albelda Pérez and Florez López, 2012) in Spain. Being able to identify the factors that influence male and female academic performance could better help administrators, instructors and policymakers establish measures to improve student academic performance; (2) companies and organizations that require accountants will be better able to hire better qualified candidates indistinctive of their gender ${ }^{[2]}$. This could benefit companies and employees from a corporate social responsibility stance as well as (3) governments, since highly qualified postgraduate accounting students could offer services as consultants, which would help boost the Spanish economy.

This article contributes to current literature by specifically examining and comparing the factors that impact academic performance of male and female accounting students, whereas prior studies focused on determining whether or not gender impacts overall academic performance (Gammie, Paver, Gammie and Duncan, 2003; Gracia and Jenkins, 2003; Martí-Ballester, 2012).

The Tobit model provides a consistent and efficient estimation tool (Greene, 2018) when the value of the dependent variable (academic performance) was set at $0-10$ points, unlike the ordinary least square technique implemented by Gracia and Jenkins (2003) or the Mann-Whitney analysis adopted by Gammie et al. (2003), where samples are not highly censored as in this study.

This paper is organized as follows: Section 2 of this article includes a literature review and hypothesis. Section 3 outlines the research method, data sources and measures of variables. The results from regression models used are discussed in Section 4 followed by the conclusion.

\section{Literature Review and Hypothesis}

According to Castagnetti and Rosti (2009), empirical evidence shows that female students outperform male students at Italian Universities, which is apparently also the case in Europe and the United States (Sheard, 2009; Woodfield, Jessop and McMillan, 2006; Buchmann and DiPrete, 2006). However, the impact on gender effect may vary depending on the field of study. Previous studies reveal that gender may be a determinant of student academic performance in accounting programs (Gammie et al. 2003; Gracia and Jenkins 2003; Martí-Ballester, 2012).

However, these studies have contradictory results. Kherfi (2008) states that male students in accounting programs have a higher academic performance than female students, whereas, Martí-Ballester (2012), Gammie et al (2003) and Gracia and Jenkins (2003) state the opposite, that female students have higher academic achievements than male students.

This article examines those factors that lead to differences in academic performance based on gender through human capital theory. According to this theory, academic performance increases individual productivity, suggesting that females are more valuable in the labour market than males (Castagnetti and Rosti, 2009); Thus, the learning process is similar to production. Student academic grades (outputs) may, therefore, be correlated as a measure of how different factors (inputs) impact grades.

Academic success has traditionally been associated with cognitive abilities. In accounting programs, students with better intellectual abilities have demonstrated higher academic performance (Martí-Ballester, 2012; Hosal-Akman and Simga-Mugan, 2010). However, cognitive abilities may vary depending on gender, according to Strand, Deary and Smith (2006) who state that such differences between male and female students depend on the kind of task. Previous studies reveal that males excel in spatial tasks and quantitative reasoning abilities while women obtain better results in verbal reasoning tasks and writing essays - a rationale 
for the higher number of females majoring in fields associated with English and males in Math-related fields (Calvin, Fernandes, Smith, Visscher and Deary, 2010). These differences are also age-dependent and more apparent in adults than young children, as stated by Lohman and Lakin (2009). Since Accounting is a Mathematics-based course requiring quantitative or numerate skills, it is more likely that male students would outperform their female counterparts (Gammie et al., 2003) in these programs.

From a biological perspective, these gender differences in specific cognitive skills could be related to gender differences in brain volume, favoring men, who have, on average, larger brains volume than women (Burgaleta et al., 2012). This excess of brain size could reinforce male visuospatial skills. On the other hand, although women and men differ in brain volume they do not differ in general cognitive abilities, as shown by Dolan et al. (2006) and Burgaleta et al. (2012). Therefore, gender differences in academic performance are not related with general cognitive abilities but with individual differences in specific reasoning abilities (Calvin et al., 2010). Since gender does not impact mean general cognitive ability, gender differences in academic performance may be due to a range of behavioral, psychological and/or social factors (Van Langen, RekersMombarg y Dekkers, 2006; Spinath, Spinath and Plomin, 2008). In this sense, societies could hold gender stereotypes associated with skills, subjects and workforce status where women are stereotyped as possessing inferior quantitative reasoning abilities and spatial skills.

In Israel and the United States, Accounting, Math, Physics and Computer Science fields have been considered to be male-dominated fields, according to Feniger (2011) and Miller, Blessing and Schwartz (2006). Such stereotypes lead to an under-representation of women in high school Science, Math and Technology-classes as well as college-level Science and Engineering Programs (Sonnert and Fox 2012; Van Langen et al., 2006). This leads to reduced academic performance (Hoffman, Gneezy and List, 2011) with gender gaps in certain areas of the workforce (Hoffman et al., 2011; Sonner and Fox 2012).

In Spain, Accounting is included as a high school course in the Social Sciences mainly chosen by female students, which has encouraged a change in Accounting being perceived as a male-dominated subject. Those students with prior knowledge of Accounting are more likely to pass Financial Accounting courses in college than those with no past experienced, according to Hartnett, Römcke and Yap (2004). It can be, therefore hypothesized that:

H1: University admissions grades affect both male and female academic performance similarly.

H2: Female and male students who took business classes during high school outperformed fellow students with a Science and Technology background. Student age had a similar effect on both male and female academic performance.

H3: Female and male students with a Social Science focus in high school outperformed their peers who focused on Technology and Science in high school.

H4: Student age had a similar impact on male and female academic performance.

Society also upholds the stereotype that students from families of lower income families are perceived to be less likely to achieve academically. (Cohen and García 2008). Destin (2013) suggests that higherincome parents are able to invest more human capital in their children, increasing the probability that their children will attend competitive universities and perform better academically than those students belonging to lower social classes and lower income ranks whose parents have historically invested only in the education of their sons (Wells, Seifert, Park, Padgett and Umbach, 2011; Buchmann and DiPetre, 2006). It is, therefore hypothesized that: H5: Attaining financial aid/scholarships had a greater impact on female academic performance than male academic performance.

Today, both female and male students have similar access to parental resources (DiPrete and Buchmann, 2006), as a result of changes in cultural perception. Both males and females can also accede to governmentsponsored scholarships and help diminish the impact of family income disparities, which is particularly beneficial to female students from low-income families, according to Buchmann and DiPetre (2006). It can, therefore, be hypothesized that scholarships have a greater impact on female academic performance. 
Such cultural changes may have influenced parental expectations about their children's academic achievements, which, from a psychological perspective, motivates female students to make more of an effort to achieve higher grades than their male counterparts (Pearce, 2006; Yamamoto and Holloway, 2010), strive to adhere to study schedules, academic goals and activities (Woodfield et al., 2006), improve their study habits (Dayioglu y Turut-Asik, 2007) and (2) attending class more regularly (Sheard, 2009), thus allowing females to better adapt to the rigors of contemporary higher education and accept learning patterns more readily (Smith, 2004). Such behavioral differences could lead to female students outperforming male students in higher education (Woodfield et al., 2006) with fewer female repeaters, specifically in the field of Accounting (Martí-Ballester, 2012). It can, therefore, be hypothesized that:

H6: Individual student effort has a greater impact on female academic performance than that of males with fewer female repeaters than males.

H7: Repetition of a course has a lower impact on female academic performance than that in males.

Male students with greater Math skills tend to target Economics rather than Business degrees since the former includes courses requiring mathematical skills than the latter. Since Accounting also requires Math skills, male students who are majoring in Economics are more likely to have a better academic performance in Financial Accounting than their female counterparts majoring in Business. It may, therefore, be hypothesized that:

H8: The degree on which a student is enrolled has a greater effect on male academic performance than on female academic performance.

Students that work in in the private sector may prefer to attend afternoon class because they usually have to work in the morning. Whereas female students who work and study have better time-management skills, male students may find it difficult to balance classes, work and home lives (Pearce, 2006), which could increase their probability of failure. Therefore, it is hypothesized that:

H9: The time of the day in which a course is offered has less effect on female academic performance than on male academic performance.

Student preference for a specific class time would make it possible to fill some Financial Accounting classes but not others, leading to differences in class size. Female students usually prefer smaller classes (Ravenscroft and Buckless, 1992), which would allow them to benefit from better interaction with the instructor (McKeachie, 1986) and therefore achieve better academic performance than their male counterparts. It may, therefore, be hypothesized that:

H10: The size of accounting classes has a greater negative effect on female academic performance than on male academic performance.

Previous authors have stated that female students have better verbal abilities than their male counterparts, while male students excel in spatial tasks and quantitative reasoning abilities. This could affect the interaction between the male student and the lecturer. Male students' abilities could be more aligned with part-time lecturers, who are concurrently employed in the private sector and can transfer their work experience to students (Bettinger and Long, 2010). On the contrary, the verbal abilities of female students allow them to interact with part-time and full-time lecturers. Therefore, it is hypothesized that:

H11: The category of lecturer only affects the academic performance of male students.

The global crisis that began in 2007 led the Spanish government to reduce the budget allotted to universities, which could have deteriorated the quality of higher education over time thereby affecting female and male student academic performance. Therefore, it is hypothesized that:

H12: The academic year in which the student took the Financial Accounting course impacts the academic performance of all students (female and male). 


\section{Research Approach}

\section{Course Description}

Financial Accounting is a compulsory module for freshman students majoring in Business Administration or in the Joint Honors Program for Business Administration and BA Law at the Autonomous University of Barcelona. Every year in June or September, students must select which of the eight sections of the module they will attend that year and are unable to change their selection thereafter, which eliminates any problems associated with self-selection. When the students enroll in the course they do not know which instructor will be teaching the classes. Each class meets for three hours and forty-five minutes during the week. In the Financial Accounting module, all lecturers use the same class material (PowerPoint presentations, textbooks and exercises which have not been modified since 2007 when Spain's Accounting Law was changed ${ }^{[3]}$ ). All the students took the same exams and the exam questions were changed on a yearly basis with the same grading method for marking the exams and homework during the period. The score obtained by the students is between 0 and 10 points, 5 being the passing grade.

\section{Sample Selection}

Data for this article is based on undergraduate student records provided by the Student Records Service of the Autonomous University of Barcelona (Student Records Service, personal communication, February 1, 2010), thereby eliminating any issues associated with student-provided data. The Student Records Service provides it with data reflecting the academic standing of students enrolled in the Financial Accounting module at the Autonomous University of Barcelona from June from 2006 to 2009. The original data included 3,317 students, later reduced to 3,219 as a result of missing information. Out of the 3,219 students, 1,471 are female and 1,748 males.

This article analyzes the male and female student performance in Financial Accounting courses obtained at the end of the academic year, the student major (BSc Economics, BSc Business Administration or Joint Honors BSc Business Administration and BA Law), the group in which the student is enrolled; the instructor responsible for the group and confirmation that all instructors have used the same PowerPoint presentations, textbooks, exercises and e-learning platform, the instructor's time commitment (full-time or part-time); the student's gender and age; whether the student receives financial aid; pre-university studies, university entrance exam score and whether or not the student is a course repeater.

\section{Measuring Variables}

Dependent and independent variables are defined as follows:

\section{Dependent Variable}

The dependent variable used in this article is academic performance (ACPER), assessed according to the student's final grade which is based on two mid-semester exams each worth $11.25 \%$, two final semester exams each comprising $11.25 \%$, two end of semester exams, each which constitute $22.5 \%$ and homework completed during the year worth $10 \%$. The score for this measure is between 0 to 10 points, 5 being the passing grade. This measure considers the impact of individual student characteristics on their academic performance and avoids the aggregation effect created when the average class grade is used (Kennedy and Siegfried, 1997). 


\section{Independent Variables}

Fourteen explanatory variables are used in this study. The first, referred to as UES, represents the effect of cognitive skills on student academic performance which is assessed using the university entrance score ${ }^{[4]}$ as a proxy, as proposed by Dayioglu and Turut-Asik (2007) and Martí-Ballester (2012). Sonnert and Fox (2012), demonstrate that a student's previous knowledge is a significant indicator of academic performance. However, Swope and Schmitt (2006) find differences in the relative importance of prior Scholastic Aptitude Tests (SATs) results (both Mathematical and Verbal sections) in predicting student academic performance.

Thus, prior mathematics SATs have a greater effect on male students' academic performance than on their female counterparts, while prior verbal SATs have a larger influence on female students' academic performance than on that of male students (Sonnert y Fox, 2012). This could be due to the existence of gender differences in the specific cognitive skills as mentioned by Strand et al. (2006) and Calvin et al. (2010) which may lead female students to specialize in social behavioral and life sciences in secondary education while male students could tend to be over-represented in engineering or technical branches as pointed out by Sonnert and Fox (2012).

This could lead to female students performing better than male students in financial accounting because a larger number of female than male students have studied accounting in pre-university studies, as the social and the business specialization in secondary education include accounting subjects and/or economics ${ }^{[5]}$ subjects (Hartnett et al. 2004). For this reason, this study includes the dummy variable SOCIAL which takes a value of 1 if the students have completed pre-university social studies and 0 if not and dummy variable BUSINESS which takes a value of 1 if the students have completed pre-university Business studies and 0 if they have not.

Gender differences for specific cognitive skills may increase with age, as state Lohman and Lakin (2009), thereby increasing the academic performance gap between male and female university students. This study takes this into account by introducing the AGE variable which indicates the number of years since the birth of the student and June $30^{\text {th }}$ in the year which the student studied that subject matter: 2006, 2007, 2008, 2009.

Cognitive abilities could also vary depending on family income since higher-income parents are able to invest more human capital in their children than low-income parents. To reduce the effect of family income disparities, certain countries offer scholarships, thus providing a greater benefit for female students from low-income parents according to Buchmann and DiPetre (2006) since low-income parents tend to invest more in the education of their sons over their daughters (Wells et al., 2011). As a result, the Ministry of Education of Spain, local governments and universities offer financial aid to freshman students from lowincome backgrounds. In the sophomore year and afterwards, the number of credits and student grade point average is considered.

Since the Financial accounting Module is given in the first year of undergraduate Economics, Business Administration and Management as well as joint honors Business Administration and Law, this article analyzes the effect of a student's socio-economic background on his or her academic performance by introducing into this study a dummy variable, SOCECO, which has the value of 1 if an Accounting student received financial aid during the academic year and 0 if they did not receive any aid.

Scholarships may motivate a student from a low-income family to pass the year in order to renew his or her grant. The refusal to award an education grant could hinder students from continuing their university education. These students would then become part of a poorly trained workforce in a labor market characterized by the existence of wage differences favoring men (International Labor Organization, 2003). The conditions of the labor market lead female students to be more motivated and make a greater effort to pass their modules than male students. For this reason, this study will introduce the explanatory variable 
EFFORT, which represents the number of credits passed by the student during the year, without taking into account the credits corresponding to passing the financial accounting module.

As female students are more motivated to make an effort to pass than male students, it's likely that the number of repeating students will be lower amongst female students. These repeating students are familiar with teaching-learning and evaluation strategies. However, they could be demotivated due to past academic failure, which may affect their academic performance. For this reason, this study includes the dummy variable REPSTUD, which has a value of 1 if the student is repeating the accounting module and 0 if the student is a new entrant in the university.

Given that male students have more mathematical skills than female students, more of the former might enroll for economics degrees than the latter, as economics degrees contain more modules that require mathematical skills in comparison with business degrees. Additionally, accounting subjects also require mathematics skills, so it is likely that male students enrolled for economics degrees will achieve better academic performance in financial accounting than their male counterparts on business degrees. For this reason, this study includes the dummy variable DSBAM which takes the value of 1 if the student is enrolled in BSc Business Administration and Management and 0 if the student is enrolled in BSc Economics.

Kherfi (2008) states that the time of the class influences students' academic performance, probably because those that attend morning class are sleep-deprived and find it difficult to retain knowledge. For this reason, this study also takes into account the time at which the student attends, introducing the dummy variable AFTERNOON which has a value of 1 if the student attends class in the afternoon and 0 if they attend class in the morning.

The existence of many students with preferences for a specific class time may mean that some financial accounting classes are full, generating differences in size. Female students usually prefer smaller classes (Ravenscroft y Buckless, 1992), which would allow them to benefit from better interaction with the lecturer (McKeachie, 1986) and therefore achieve better academic performance than their male counterparts. Thus, differences in the size of the class attended by students are controlled by the variable SGROUP which indicates the number of students enrolled in each group during the period considered.

Given that other studies, Martí-Ballester (2017) and Kherfi (2008) show that professor and classroom characteristics could influence a student's academic performance, this study controls for the professional status of the lecturer, class size, the year and the time at which students attend class. The lecturers who work in full-time positions are more qualified (they possess doctoral degrees), have increased office hours, use more technology, have higher writing expectations, and are hired at higher rates of compensation than lecturers who are employed in part-time positions (Jacoby, 2006), enabling them to (1) use more challenging instructional methods, (2) have different instructional practices characterized as more time-intensive, (3) provide strong advice (Jacoby, 2006) and (4) have greater incentives to do well (Jacoby, 2006). On the contrary, part-time lecturers, who must have concurrent employment in the private sector, may improve students' educational experiences (Bettinger and Long, 2010) affecting student learning. Thus, this study includes the dummy variable LECTURER with a value of 1 if the lecturer only teaches in the university and 0 if the lecturer works both in the university and in a private company.

To control the effect of economic crisis on students' academic performance this study also introduces the control variable YEAR with a value of 1 if the student is enrolled in the financial accounting module in the year indicated $(2006,2007$ or 2008) and 0 if not. The variance inflation factor (VIF) and the matrix indicating correlation coefficients between independent variables ${ }^{[6]}$ shows that there are no multicollinearity problems in this model (Sharma y James, 1981). Table 1 (Panel A and B) provides descriptive statistics for all variables. 
TABLE 1

Dependent and Independent Variable Descriptive Statistics from 2006 to 2009.

\begin{tabular}{llllll}
\hline Variable & Mean & Median & $\begin{array}{l}\text { Standard } \\
\text { Deviation }\end{array}$ & Minimum & Maximum \\
\hline Total Students & & & & & \\
ACPER & 3.41 & 4.00 & 2.91 & 0.00 & 10.00 \\
AGE & 21.00 & 20.10 & 3.04 & 18.03 & 55.80 \\
UES & 6.31 & 6.23 & 0.83 & 5.00 & 9.73 \\
EFFORT & 31.25 & 31.50 & 22.04 & 0.00 & 183.00 \\
SGROUP & 106.81 & 107.00 & 17.54 & 63.00 & 152.00 \\
\hline Female StudentS & & & & & \\
ACPER & 3.90 & 4.90 & 2.82 & 0.00 & 9.60 \\
AGE & 20.65 & 19.88 & 2.74 & 18.51 & 48.48 \\
UES & 6.48 & 6.38 & 0.88 & 5.00 & 9.45 \\
EFFORT & 34.66 & 38.30 & 22.02 & 0.00 & 132.00 \\
SGROUP & 105.17 & 107.00 & 17.92 & 63.00 & 152.00 \\
\hline Male StudentS & & & & & \\
ACPER & 2.99 & 2.90 & 2.92 & 0.00 & 10.00 \\
AGE & 21.29 & 20.30 & 3.24 & 18.03 & 55.80 \\
UES & 6.16 & 6.09 & 0.76 & 5.00 & 9.73 \\
EFFORT & 28.38 & 27.00 & 21.64 & 0.00 & 183.00 \\
SGROUP & 108.19 & 107.00 & 17.09 & 63.00 & 152.00 \\
\hline
\end{tabular}

Panel A: Continuous Variable

Source: Autonomous University of Barcelona (Student Records Service, personal communication, February 1, 2010)

TABLE 1

Panel B: Dichotomous Variable

\begin{tabular}{lllll}
\hline & & Females & Males & Total \\
\hline Variable & Code & Frequency & Frequency & Frequency \\
\hline \multirow{2}{*}{ SOCECO } & 0 & 1.184 & 1.588 & 2.772 \\
& 1 & 287 & 160 & 447 \\
BUSINESS & 0 & 1.449 & 1.734 & 3.183 \\
& 1 & 22 & 14 & 36 \\
SOCIAL & 0 & 348 & 679 & 1.027 \\
& 1 & 1.123 & 1.069 & 2.192 \\
TECNOLOGY & 0 & 1.145 & 1.083 & 2.228 \\
REPSTUD & 1 & 326 & 665 & 991 \\
& 0 & 977 & 1.040 & 2.017 \\
DSBAM & 1 & 494 & 708 & 1.202 \\
& 0 & 600 & 1.021 & 1.621 \\
LECTURER & 0 & 871 & 727 & 1.598 \\
& 1 & 760 & 1.139 & 1.899 \\
AFTERNOON & 0 & 1.123 & 609 & 1.320 \\
& 1 & 348 & 1.226 & 2.349 \\
\hline
\end{tabular}

Source: Autonomous University of Barcelona (Student Records Service, personal communication, February 1, 2010)

\section{Multivariate Regression Analysis}

Statistical analysis was done using the econometric STATA 11 package and a Tobit model was also used to analyze the factors that influence academic success in male and female students. Greene (2018) showed that the implementation of the Ordinary Least Squares technique provides inconsistent estimators when the dependent variable of the model is censored, as occurs in this case. To overcome this, Tobin (1958) develops a Tobit model that provides consistent and efficient estimators when the dependent variable is censored. 
Given that the dependent variable (academic performance) oscillates between 0 and 10 points with a large percentage of grades having 0 points, the following Tobit model was used (Figure 1):

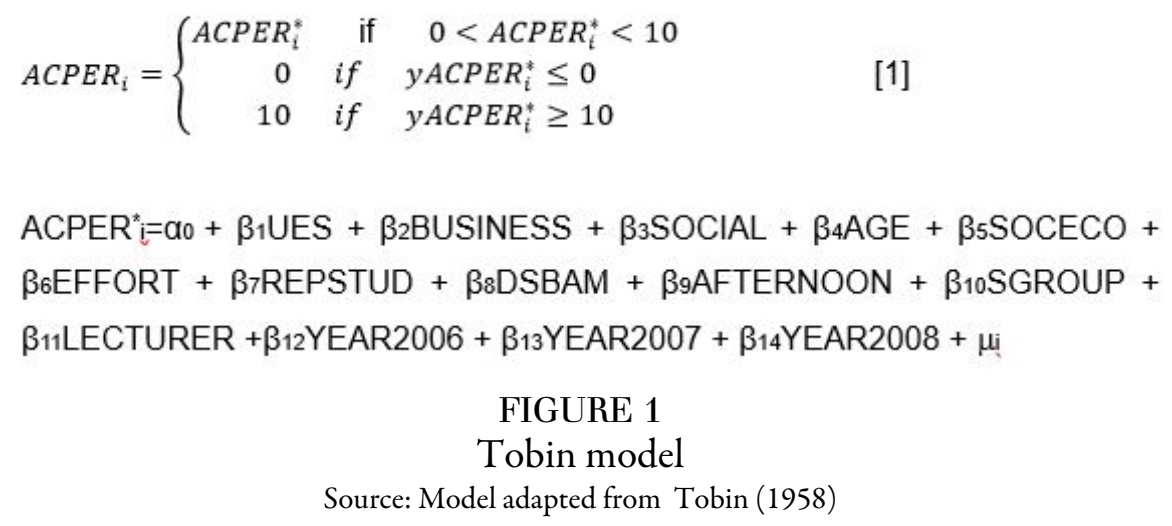

Where ACPER*i is the academic performance obtained by a female/male student. 10 is the maximum grade that a female/male student can obtain (10 points). 0 is the minimum grade that a female/male student can obtain (0 points). Coefficient $\beta_{1}$ estimates the effect associated with the variable UES; Coefficient $\beta_{2}$ is associated with the BUSINESS variable. Coefficient $\beta_{3}$ is associated with the SOCIAL variable. Coefficient $\beta_{4}$ is associated with the AGE variable. Coefficient $\beta_{5}$ estimates the impact of receiving financial aid (SOCECO) during the year on the female and male academic performance respectively. Coefficient $\beta_{6}$ is associated with the EFFORT variable. Coefficient $\beta_{7}$ is associated with the REPSTUD variable. Coefficient $\beta_{8}$ is associated with the DSBAM variable. Coefficient $\beta_{9}$ is associated with the AFTERNOON variable. Coefficient $\beta_{10}$ is associated with the SGROUP variable. Coefficient $\beta_{11}$ estimates the effect of the instructor (LECTURER) on female and male academic performance. Coefficient $\beta_{12}$ is associated with the YEAR 2006 variable. Coefficient $\beta_{13}$ is associated with the YEAR 2007 variable. Coefficient $\beta_{14}$ is associated with the YEAR 2008 variable. The residuals are ${ }_{i}{ }_{i}$

To estimate standard error, this article uses a nonparametric method, bootstrapping, which does not assume homoskedasticity and normality of errors. Furthermore, given that Kennedy and Siegfried (1997) state that the number of students in each group may produce heterogeneity, this article implements the correction proposed by Fleisher, Hashimoto and Weinberg (2002), including twenty-nine clusters for running the standard errors in the gender-specific academic performance equations of the students to counteract this problem.

The Tobit-Blinder-Oaxaca decomposition proposed by Bauer and Sinning (2010), is used to assess differences. The bootstrap technique and development in Stata by Bauer, Hahn and Sinning (2007) breaks down the overall mean gender academic performance differences as an explained component due to differences in average observable individual characteristics, and as an unexplained component resulting from differences in the estimated coefficients.

\section{RESULTS}

Table 2 shows the coefficients obtained from estimating the Tobit model in the two subsamples of male and female students majoring in Financial Accounting during the period study. The results obtained reveal the existence of differences and similarities in the factors that influence academic success depending on the gender of the student. In this regard, this article finds a positive and significant relationship between the UES variable and academic performance $\left(\beta_{1 \text { FEMALE }}=0.8348 ; p\right.$-value $<0.01 ; \beta_{1 \text { MALE }}=0.7329 ; p$-value $\left.<0.01\right)$, which supports hypothesis $(\mathrm{H} 1)$. Therefore, those students who demonstrate greater skills in pre-university 
studies achieve better academic performance with an increase of 0.83 points (female students) and 0.73 points (male students) on the average. This result is consistent with previous studies carried out by MartíBallester (2012) and Kherfi (2008). It can, therefore, be stated that prior academic performance is an important determinant of academic performance for male and female students. This finding indicates that the prior academic performance in high school can be used as primary criteria for admitting and attracting top students to Business and Accounting programs.

TABLE 2

Estimation Results

\begin{tabular}{|c|c|c|c|c|}
\hline & \multicolumn{4}{|c|}{ Tobit Coefficients } \\
\hline & Females & & Males & \\
\hline INSTRUCTOR & $\begin{array}{l}-0.1107 \\
(0.2880)\end{array}$ & & $\begin{array}{l}-0.6978 \\
(0.3537)\end{array}$ & $* *$ \\
\hline AFTERNOON & $\begin{array}{l}-0.3631 \\
(0.3021)\end{array}$ & & $\begin{array}{l}-0.9747 \\
(0.5193)\end{array}$ & * \\
\hline SOCECO & $\begin{array}{l}0.4464 \\
(0.1965)\end{array}$ & $* *$ & $\begin{array}{l}0.0934 \\
(0.2672)\end{array}$ & \\
\hline UES & $\begin{array}{l}0.8348 \\
(0.1067)\end{array}$ & $* * *$ & $\begin{array}{l}0.7329 \\
(0.1303)\end{array}$ & $* * *$ \\
\hline EFFORT & $\begin{array}{l}0.0937 \\
(0.0079)\end{array}$ & $* * *$ & $\begin{array}{l}0.1194 \\
(0.0099)\end{array}$ & $* * *$ \\
\hline REPSTUD & $\begin{array}{l}1.2441 \\
(0.3250)\end{array}$ & $* * *$ & $\begin{array}{l}0.7593 \\
(0.3146)\end{array}$ & $* *$ \\
\hline BUSINESS & $\begin{array}{l}1.8610 \\
(0.5330)\end{array}$ & $* * *$ & $\begin{array}{l}2.7374 \\
(0.7121)\end{array}$ & $* * *$ \\
\hline SOCIAL & $\begin{array}{l}0.4398 \\
(0.1568)\end{array}$ & $* * *$ & $\begin{array}{l}0.3770 \\
(0.1257)\end{array}$ & $* * *$ \\
\hline DSBAM & $\begin{array}{l}0.1375 \\
(0.2677)\end{array}$ & & $\begin{array}{l}0.5122 \\
(0.3622)\end{array}$ & \\
\hline $\mathrm{AGE}$ & $\begin{array}{l}-0.0249 \\
(0.0396)\end{array}$ & & $\begin{array}{l}-0.0737 \\
(0.0484)\end{array}$ & \\
\hline SGROUP & $\begin{array}{l}0.0095 \\
(0.0089)\end{array}$ & & $\begin{array}{l}0.0025 \\
(0.0115)\end{array}$ & \\
\hline YEAR 2006 & $\begin{array}{l}0.3865 \\
(0.3627)\end{array}$ & & $\begin{array}{l}-0.3211 \\
(0.3795)\end{array}$ & \\
\hline YEAR 2007 & $\begin{array}{l}-0.2725 \\
(0.3514)\end{array}$ & & $\begin{array}{l}-0.5571 \\
(0.4247)\end{array}$ & \\
\hline YEAR 2008 & $\begin{array}{l}-0.3609 \\
(0.3800)\end{array}$ & & $\begin{array}{l}-1.4712 \\
(0.4890)\end{array}$ & $* * *$ \\
\hline Cons & $\begin{array}{l}-6.4924 \\
1.6055\end{array}$ & $* * *$ & $\begin{array}{l}-4.5244 \\
(1.9899)\end{array}$ & $* *$ \\
\hline Observations & 1,471 & & 1,748 & \\
\hline Left-Censored & 395 & & 739 & \\
\hline Right-Censored & 0 & & 1 & \\
\hline $\begin{array}{l}\text { Log Likelihood } \\
\text { Pseudo R2 }\end{array}$ & $\begin{array}{l}-2,940.18 \\
0.1219\end{array}$ & & $\begin{array}{l}-3,150.47 \\
0.1247\end{array}$ & \\
\hline
\end{tabular}

Source: Autonomous University of Barcelona (Student Records Service, personal communication, February 1, 2010) Note: Statistical significance at the $1 \%, 5 \%$ and $10 \%$ levels is denoted by ${ }^{* * *},{ }^{* *},{ }^{*}$, respectively. Standard errors in parentheses.

The coefficient associated with the BUSINESS variable is significant and positive $\left(\beta_{2 \mathrm{FEMALE}}=1.8610\right.$; $\mathrm{p}$ value $<0.01 ; \beta_{2 \text { MALE }}=2.7374 ; \mathrm{p}$-value $\left.<0.01\right)$ and higher than the coefficient associated with the SOCIAL variable $\left(\beta_{3 \text { FEMALE }}=0.4398 ; p\right.$-value $<0.01 ; \beta_{3 \text { MALE }}=0.3770 ; p$-value $\left.<0.01\right)$. These findings indicate that female/male students who previously studied Accounting as part of high school Business courses and those with a Social Science high school background achieved 1.86 points ( 2.74 points) on average and 0.44 points ( 0.38 points) more than their female/male peers who previously completed high school Technology courses. This supports $\mathrm{H} 2$ and $\mathrm{H} 3$. Therefore, the achievement of a good academic record is proven to be significantly more feasible for those male and female students who previously studied Accounting in high school Business 
courses than for their classmates that specialized in the Social Sciences at secondary school whose syllabuses included one subject with a mix of economic contents including one unit on Accounting concepts or that specialized in Technology in high school with no prior exposure to Accounting. This could point to the existence of a close correspondence between high school and university curricula. This result is consistent with the empirical evidence provided by Hartnett et al. (2004).

On the contrary, the coefficient associated with the AGE variable is negative but not significant $\left(\beta_{4 F E M A L E}=-0.0249 ; p\right.$-value $>0.10 ; \beta_{4 M A L E}=-0.0737 ; p$-value $\left.>0.10\right)$, indicating that younger (female and male) students acquire similar accounting skills and abilities to older (female and male) students, supporting H4. This agrees with the findings of Dolan et al. (2006) that female and male students do not differ in cognitive abilities, regardless of their age.

On the other hand, this study finds a positive and significant relationship between the SOCEC variable and the AP variable in the female model $(\beta 5=0.4464$; $\mathrm{p}$-value $<0.05)$, whereas this relationship is notsignificant in the male model $\left(\beta_{5}=0.0934 ; \mathrm{p}\right.$-value $\left.>0.10\right)$. Therefore, female students benefiting from financial aid achieve significantly better academic performance than those who do not receive financial aid, increasing their academic performance by 0.45 points on average, which supports hypothesis $\mathrm{H} 5$. This could be explained by female students who receive scholarships being more motivated than male students in obtaining good grades in order to renew their financial aid and continue with their studies. Otherwise, women would be forced to find a job in a labor market where women with less education are more likely to lose their jobs and have greater difficulties finding a new job than men with less education, as pointed out by the International Labor Organization (2003).

The effort made by students during the year (measured through the EFFORT variable) also seems to have a positive and significant influence on the student performance in the subject ( $\beta_{6 \mathrm{FEMALE}}=0.0937$; $\mathrm{p}$ value $<0.01 ; \beta_{6 \mathrm{MALE}}=0.1194 ; \mathrm{p}$-value $<0.01$ ), taking the Tobit estimators into account. Thus, those male and female students who passed a greater number of credits during the year obtained a better academic performance increasing it by 0.09 (female students) and 0.12 (male students) points per credit passed. The effect of student effort on academic performance is slightly higher for male than female students, indicating that male students are slightly more motivated and work harder than their female counterparts to earn higher grades, which does not support hypothesis (H6). This result contradicts the findings of Pearce (2006) and Yamamoto and Holloway (2010).

This article also finds that the coefficient associated with the REPEAT variable has a significant and positive effect on student academic performance $\left(\beta_{\text {TFEMALE }}=1.2441 ; p\right.$-value $<0.01 ; \beta_{7 \text { MALE }}=0.7593$; $p$ value $<0.05)$. Male and female students who were not able to pass previous exams increased their performance by 0.76 and 1.24 points, respectively, compared to incoming students, which contradicts hypothesis $\mathrm{H} 7$. This may be due to the fact that repeaters are more familiar with the material and the type of exam and that female students who are repeaters, make a greater effort to pass the course than their male peers.

The coefficient associated with the DSBAM variable is positive but not significant $\left(\beta_{8 \mathrm{BEMALE}}=0.1375\right.$; $\mathrm{p}$-value $>0.10 ; \beta_{8 \mathrm{MALE}}=0.5122 ; \mathrm{p}$-value $>0.10$ ), indicating that (female and male) students enrolled on economics degrees acquire similar accounting skills and abilities to (female and male) students enrolled on a Business degree, which does not support hypothesis H8. This result could be explained by the fact that Accounting requires basic mathematical abilities that are easily achieved by female and male students enrolled in either degree.

The time of the day in which male students attend class (AFTERNOON variable) significantly influences their performance. Students who attend class in the afternoon obtained worse grades than those students who attended class in the morning $\left(\beta_{9 \mathrm{MALE}}=-0.9747\right.$; $\mathrm{p}$-value $\left.<0.10\right)$ which supports hypothesis $\mathrm{H}$. Concretely, male students who attend class in the afternoon reduce their academic performance by 0.97 points on average. This could be explained by the fact that students who attend the financial accounting class in the afternoon usually work and study. Male students tend to have lower organizational and time 
management skills than female students who are better able to organize and keep track of homework and class materials. This result is consistent with Pearce (2006).

The coefficient associated with the SGROUP variable is positive but not significant $\left(\beta_{10 \mathrm{FEMALE}}=0.0095\right.$; p-value $>0.10 ; \beta_{10 M A L E}=0.0025$; $p$-value $\left.>0.10\right)$, indicating that (female and male) students in large classes acquire similar Accounting skills and abilities to (female and male) students in small classes, which does not support hypothesis H10. This finding could be due to students interacting with the lecturer in class and virtually by means of the Moodle Platform.

The type of professor teaching the course (INSTRUCTOR variable) seems to impact male academic performance $\left(\beta_{11 \mathrm{MALE}}=-0.6978\right.$; $\mathrm{p}$-value $\left.<0.05\right)$, although not the female student results $\left(\beta_{11 \mathrm{FEMALE}}=\right.$ -0.1107; p-value $>0.10)$, what supports hypothesis (H11). Male students whose professor works in a private company increase their academic performance significantly by 0.70 points on average. Thus, the professor, who also works in a private company, tends to be more effective at teaching the subject of accounting to male students than full-time faculty. This may be due to the different verbal and spatial abilities that characterize men and women. Female students could likely benefit from verbal abilities and thus be able to interact with any type of instructor, while male students require instructors with more practical experience in the industry in order to benefit from spatial abilities and obtain better grades.

The academic year when male students enrolled has a negative and significant influence on their academic performance $\left(\beta_{14 \mathrm{MALE}}=-1.4712\right.$; $\mathrm{p}$-value $\left.<0.05\right)$. This is not the case with the results of female students $\left(\beta_{14 F E M A L E}=-0.3609 ; p\right.$-value $\left.>0.10\right)$ compared to their academic performance in 2009 . This indicates that the budget restrictions did not deteriorate the quality of higher education on the consideration that 2009 was the second year of the global financial crisis. Therefore, hypothesis $\mathrm{H} 12$ is not supported.

To examine the existence of convergence in male and female academic performance during the period analyzed, this study uses a decomposition technique attributed to Bauer and Sinning (2010). This decomposition analysis yields the result, shown in Table 3. Observable characteristics explain $67.27 \%$ of the differences in academic performance between male and female students However, this article considers that this percentage could be biased if there are issues regarding omitted variables (Duncan and Sandy, 2013) transferring some of the unexplained portion of the gap inappropriately into the explained portion.

TABLE 3

Decomposition Results

\begin{tabular}{lll}
\hline & Coefficients & In \% of $\Delta$ tobit \\
\hline$\Delta$ tobit & $0.9613^{* * *}$ & 100 \\
Explained Portion & $0.6467^{* * *}$ & 67.27 \\
Unexplained Portion & $0.3146^{* * *}$ & 32.73 \\
\hline
\end{tabular}

Source: Autonomous University of Barcelona (Student Records Service, personal communication, February 1, 2010) Note: Statistical significance at $1 \%, 5 \%$ and $10 \%$ denoted by ${ }^{* * *},{ }^{* *},{ }^{*}$, respectively.

\section{Conclusions}

Previous research has found disparate proof on the differences in academic performance obtained by men and women in a university setting. This could be due to the methodology used or to the different geographic scopes and time frames analyzed. However, these studies do not explore the factors that produce the gender gap in academic performance. For this reason and in order to provide greater empirical evidence to a line of investigation that is still quite underdeveloped, this article analyzes the differences in academic performance between males and females in the field of Accounting and provides information on 3,219 students, 1,748 of which are men and 1,471 women, all enrolled in Financial Accounting during the period from 2006-2009. 
A Tobit model was implemented for these data and the decomposition of the estimation of the Tobit model as proposed by Tobin (1958) and Bauer and Sinning (2010), respectively, applying the bootstrap technique and correcting the problem of heterogeneity. This methodology enables it to obtain consistent and efficient estimators when there is a censored dependent variable (academic performance), as occurs in this case.

The results show that students' cognitive skills positively influence their academic performance, which supports hypothesis H1. So, students' university entrance grades could help lecturers to identify those students that could have difficulties and therefore monitor them during their learning process. This study also finds that students with prior knowledge of accountancy outperform their peers that specialized in technological science in secondary education, thereby supporting hypotheses $\mathrm{H} 2$ and $\mathrm{H} 3$. In the light of these findings, university administrators should take into account previous studies of accounting when selecting students for their Business and Economics degrees.

As predicted by hypothesis $\mathrm{H} 4$, student age has a similar effect on female and male academic performance, which is probably due to the determination of younger students being balanced by the maturity of older students and therefore having a similar effect on their academic performance. The findings also show that female students benefiting from a grant achieve better academic performance in relation to their peers, thus supporting hypothesis 5. The Departments of Education of different autonomous regions, the Ministry of Education and universities should distribute grants among female and male students by giving preference to female students with fewer economic resources. The effort that male students put into courses in all subjects for which they are enrolled has a higher effect on academic performance than that of female students, which contradicts hypothesis H6. Lecturers should provide their students with knowledge management tools to help them to organize and control their learning processes.

However, female students who did not pass their Financial Accounting credits make a greater effort to pass the subject in the following academic year in comparison with their male peers, which is incongruent with hypothesis H7. Previous failure at subjects motivates female students to do better to a greater extent than it does male students. Contrary to hypothesis H8, the degree on which a student is enrolled has no effect on student performance, thereby indicating that the basic mathematical skills required for accountancy subjects are easily obtained by female and male students.

The time when students attend class only significantly affects male students' academic performance, thus supporting hypothesis $\mathrm{H}$ 9. Male students that attend class in the afternoon and are likely to work for companies in the morning find it harder to organize their time than their female peers do. This article also finds that class size does not affect students' academic performance, which does not support hypothesis $\mathrm{H} 10$ and indicates that the lack of interaction between lecturer and student in class can be balanced with online interaction. University administrators should encourage the use of online tools in order to resolve specific and individual doubts.

However, male students achieve better academic performance when their lecturer works for a private company, which supports hypothesis H11. Lecturers who have experience in private companies as accountants seem to positively influence male students' academic performance. Therefore, to improve male's academic performance in class, the coordinator and professors could modify teaching materials used to the explain the theoretical content, by adding practical examples in order to simulate real situations that employees could have to face when performing accounting functions at companies. It would not be detrimental for the students to be able to receive the material used by the instructor to teach the Financial Accounting course. The financial crisis that led governments to reduce the budget allowance for universities did not deteriorate the quality of higher education, which does not support hypothesis H12.

The findings obtained show that there are differences in the factors that influence male and female academic performance. Specifically, $67.27 \%$ of the differences in academic performance between males and females can be attributed to characteristics observable in the proposed model. 
Finally, it is important to mention that shortcomings in this study creates interesting challenges for further researcher. This article does not take into account the type of higher education institution (public or private), learning style of student social life which may impact academic performance (Gammie et al., 2003) and influence the decomposition technique, inappropriately transferring some of the unexplained portion of the gap to the explained portion (Duncan and Sandy, 2013). Future research should examine the effect of the type of higher education institution (public or private) and the learning style or the social life of students on the students' academic performance.

\section{REFERENCES}

Albelda Pérez, E. y Florez López, R. (2012). Equipos de trabajo en contabilidad financiera para el registro de operaciones mediante documentos reales. Revista UPO INNOVA, 1, 36-48.

Bauer, T.K.; Hahn, M. y Sinning, M. (April, 2007). Blinder-Oaxaca Decomposition for Linear and Non-linear Models. In J. Giesecke, J.P. Haisken-DeNew and U. Kohler (Presidents). Fifth German Stata Users Group Meeting. Paper presented at the Fifth German Stata Users Group Meeting organized by Stata, Berlin.

Bauer, T.K. y Sinning, M. (2010). Blinder-Oaxaca decomposition for Tobit models. Applied Economics, 42(12), 1569-1575.

Bettinger, E. P. y Long, B. T. (2010). Does cheaper mean better? The impact of using adjunct instructors on student outcomes. The Review of Economics and Statistics, 92(3), 598-613.

Burgaleta, M., Head, K., Álvarez, J., Martínez, K., Escorial, S., Haier, R. y Colom, R. (2012). Sex differences in brain volume are related to specific skills, not to general intelligence. Intelligence, 40(1), 60-68.

Buchmann, C. y DiPrete, T. (2006). The growing female advantage in college completion: The role of family background and academic achievement. American Sociological Review, 71(4), 515-541.

Calvin, C.M., Fernandes, C., Smith, P., Visscher, P.M. y Deary, I.J. (2010). Sex, intelligence and educational achievement in a national cohort of over 175,000 11-year-old schoolchildren in England. Intelligence, 38(4), 424-432.

Castagnetti, C. y Rosti, L. (2009). Effort allocation in tournaments: The effect of gender on academic performance in Italian universities. Economics of Education Review, 28(3), 357-369.

Cohen, G. L. y Garcia, J. (2008). Identity, belonging, and achievement: A model, interventions, implications. Current Directions in Psychological Science, 17(6), 365-369.

Dayioglu, M. y Turut-Asik, S. (2007). Gender differences in academic performance in a large public university in Turkey. Higher Education, 53(2), 255-277.

Destin, M. (2013). Integrating resource-based and person-based approaches to understanding wealth effects on school achievement. Economics of Education Review, 33, 171-178.

DiPrete, T. y Buchmann, C. (2006). Gender-specific trends in the value of education and the emerging gender gap in college completion. Demography, 43(1), 1-24.

Dolan, C. V., Colom, R., Abad, F. J., Wicherts, J. M., Hessen, D. J. y van de Sluis, S. (2006). Multi-group covariance and mean structure modeling of the relationship between theWAIS-III common factors and sex and educational attainment in Spain. Intelligence, 34(2), 193-210.

Duncan, K. y Sandy, J. (2013). Using the Blinder-Oaxaca Decomposition Method to Measure Racial Bias in Achievement Tests. Review of Black Political Economy, 40, 185-206.

Feniger, Y. (2011). The Gender Gap in Advanced Math and Science Course Taking: Does Same-Sex Education Make A Difference? Sex Roles, 65(9), 670-679.

Fleisher, B., Hashimoto, M. y Weinberg, B.A. (2002). Foreign-GTAs can be effective teachers of economics. The Journal of Economic Education, 33(4), 299-325.

Gammie, E., Paver, B., Gammie, B. y Duncan, F. (2003). Gender differences in accounting education: an undergraduate exploration. Accounting Education: An International Journal, 12(2), 177-196. 
Gracia, L. y Jenkins, E. (2003). A quantitative exploration of student performance on an undergraduate accounting programme of study. Accounting Education: An International Journal, 12(1), 15-32.

Greene, W.H. (2018). Econometric Analysis. Englewood Cliffs: Prentice Hall.

Hartnett, N., Römcke, J. y Yap, C. (2004). Student performance in tertiary-level accounting: an international student focus. Accounting and Finance, 44(2), 163-185.

Hoffman, M., Gneezy, U. y List, J.A. (2011). Nurture affects gender differences in spatial abilities. Proceedings of the National Academy of Sciences, 108(36), 14786-14788.

Hosal-Akman, N. y Simga-Mugan, C. (2010). An assessment of the effects of teaching methods on academic performance of students in accounting courses. Innovations in Education and Teaching International, 47(3), 251-260.

International Labor Organization. (2003). La hora de la igualdad en el trabajo. Informe global con arreglo al seguimiento de la Declaración de la OIT relativa a los principios y derechos fundamentales en el trabajo (Informe No. I). Ginebra: Oficina Internacional del Trabajo.

Jacoby, D. (2006). Effects of part-time faculty employment on community college graduation rates. The Journal of Higher Education, 77(6), 1081-1103.

Kennedy, P.E. y Siegfried, J.J. (1997). Class size and achievement in introductory economics: evidence from the TUCE III data. Economics of Education Review, 16(4), 385-394.

Kherfi, S. (2008). Economic Education in the Middle East: Are the Determinants of Success in Introductory Economics Any Different? Journal of Economic Education, 39(1), 22-40.

Lohman, D.F. y Lakin, J. (2009). Consistencies in Sex Differences on the Cognitive Abilities Test across Countries, Grades, and Cohorts. British Journal of Educational Psychology, 79(2), 389-407.

Martí Ballester, C. P. (2012). Analysis of the Factors that Influence the Academic Performance of Financial Accounting Students using Binary Choice Models. Revista Brasileira de Gestão de Negócios, 14(45), 379-399.

Martí-Ballester, C.P. (2017). ¿Profesores con más experiencia suponen mayores oportunidades de aprendizaje? Relación entre las características de los profesores y el rendimiento académico de los estudiantes en la asignatura de Contabilidad Financiera de una universidad española. Ciencias Sociales y Educación, 6(12), 23-44.

McKeachie, W. J. (1986). Teaching psychology: Research and experience. In V. P. Makoskey. (Ed.) The G. Stanley Hall Lecture Series. (pp. 165-191). Washington, United States: American Psychological Association.

Miller, P. H., Blessing, J. S. y Schwartz, S. (2006). Gender differences in high-school students' views about science. International Journal of Science Education, 28(4), 363-381.

Pearce, R.R. (2006). Effects of cultural and social structural factors on the achievement of white and Chinese American students at school transition points. American Educational Research Journal, 43(1), 75-101.

Ravenscroft, S.P. y Buckless, F.A. (1992). The effect of grading policies and student gender on academic performance. Journal of Accounting Education, 10(1), 163-179.

Sharma S. y James, WL. (1981). Latent root regression: an alternate procedure for estimating parameters in the presence of multicollinearity. Journal of Marketing Research, 18, 154-161.

Sheard, M. (2009). Hardiness commitment, gender, and age differentiate university academic performance. British Journal of Educational Psychology, 79(1), 189-204.

Smith, F. (2004). It's not all about grades'. Accounting for gendered degree results in geography at Brunel University. Journal of Geography in Higher Education, 28(2), 167-178.

Sonnert, G. y Fox, M.F. (2012). Women, Men, and Academic Performance in Science and Engineering: The Gender Difference in Undergraduate Grade Point Averages. The Journal of Higher Education, 83(1), 73-101.

Spinath, B., Spinath, F. M. y Plomin, R. (2008). The nature and nurture of intelligence and motivation in the origins of sex differences in elementary school achievement. European Journal of Personality, 22(3), 211-229.

Strand, S., Deary, I. J. y Smith, P. (2006). Sex differences in Cognitive Abilities Test scores: A UK national picture. British Journal of Educational Psychology, 76(3), 463-480. 
Swope, K.J. y Schmitt, P.M. (2006). The Performance of Economics Graduates over the Entire Curriculum: The Determinants of Success. Journal of Economic Education, 37(4), 387-394.

Tobin, J. (1958). Estimation of relationships for limited dependent variables. Econometrica: Journal of the Econometric Society, 24-36.

Van Langen, A., Rekers-Mombarg, L. y Dekkers, H. (2006). Sex-related differences in the determinants and process of science and mathematics choice in pre-university education. International Journal of Science Education, 28(1), $71-94$.

Wells, R., Seifert, T., Park, S., Padgett, R. y Umbach, P. (2011). Why Do More Women Want to Earn a Four-Year Degree? Exploring the Effects of Gender, Social Origin, and Social Capital on Educational Expectations. The Journal of Higher Education, 82(1), 1-32.

Woodfield, R., Jessop, D. y McMillan, L. (2006). Gender differences in undergraduate attendance rates. Studies in Higher Education, 31(1), 1-22.

Yamamoto, Y. y Holloway, S.D. (2010). Parental expectations and children's academic performance in sociocultural context. Educational Psychology Review, 22(3), 189-214.

\section{Notes}

[1] In this case, male students have a much higher drop-out rate than female students.

[2] According to the Spanish Ministry of Employment and Social Security (2012) firms hired more female than male accountants in 2011.

[3] This change does not affect this analysis because the lessons are the same. They only update the content of each lesson according to the new law. For example, with the former Spanish Accounting Law, the following structure was used: (1) Accounting Principles - (2) Accounting Charts - (3) Definitions and Accounting Entries - (4) Annual Accounts - (5) Recognition and Measurement Standards; The new Spanish Accounting Law uses the following structure: (1) Accounting Framework - (2) Recognition and Measurement Standards - (3) Annual Accounts - (4) Accounting Charts - (5) Definitions and Accounting Entries.

[4] Each university calculates students' university entrance grades by averaging the grades obtained in the entrance examination and the mean grades obtained in secondary education. The entrance exams that students take are the same for each regional government in a specific year. The mean grade obtained in secondary education is calculated by taking into account the grades obtained in common subjects (history, geography, mathematics, English language, natural sciences, Spanish language and so on) and in subjects shared by disciplines (pure mathematics, higher physics, biology, higher chemistry, technological drawing in science; mathematics applied to social science, history, literature, economics, geography, French language in Social Sciences; and so on). Almost all students majoring in undergraduate Business Administration and Economics were enrolled in Social Science $(2,192$ students) or Technology courses (991 students) during high school. In addition, the student may have graduated from a vocational training high school. As a result, students from this sample (36) majoring in Business Administration and Economics had Business training in high school, i.e. Accounting, Finance, Business Administration, etc.

[5] Economics subjects include accounting content.

[6] These results are available from the authors upon request.

\section{BY-NC-ND}

